\title{
Analisis Hubungan Kecepatan Gelombang Dengan Kuat Tekan Beton Menggunakan Metode UPV
}

\author{
Anggia Eta Rizkiasari*1, Abdul Rouf ${ }^{2}$ \\ ${ }^{1}$ Program Studi Elektronika dan Instrumentasi, FMIPA UGM, Yogyakarta \\ ${ }^{2}$ Departemen Ilmu Komputer dan Elektronika, FMIPA UGM, Yogyakarta \\ e-mail: * ${ }^{1}$ eta.anggia@gmail.com, ${ }^{2}$ rouf@mail.ugm.ac.id
}

\begin{abstract}
Abstrak
Hingga saat ini penggunaan beton sebagai bahan bangunan masih banyak digunakan untuk struktur bangunan. Sangat penting untuk melakukan pengujian kuat tekan beton sebagai salah satu faktor untuk mengetahui kualitas suatu beton. NDT (Non-Destructive Testing) adalah metode pengujian kualitas benda padat tanpa merusak benda tersebut. Pengujian dengan metode NDT dianggap lebih efisien dibandingkan dengan metode destructive test. Salah satu metode untuk melakukan pengujian secara NDT adalah dengan memanfaatkan UPV (Ultrasonic Pulse Velocity).

UPV adalah metode untuk memperkirakan kuat tekan beton yang didasarkan pada hubungan kecepatan gelombang ultrasonik melalui beton dengan kuat tekan beton itu sendiri. Cara kerja pengujian UPV adalah dengan memancarkan gelombang ultrasonik sebesar $40 \mathrm{kHz}$ melalui beton untuk memperoleh waktu tempuh gelombang. Kemudian waktu yang dihasilkan akan dihitung nilai kecepatannya dan kemudian akan dikonversikan menjadi kuat tekan beton.

Sistem pengukuran kuat tekan beton untuk kualitas beton tinggi menggunakan metode UPV dapat dirancang dengan memanfaatkan hubungan kecepatan gelombang ultrasonik dengan kuat tekan beton. Berdasarkan hasil pengujian, nilai kesalahan rata-rata pengujian kuat tekan beton sebesar 3,04\% dengan kesalahan maksimal sebesar 6,63\%.
\end{abstract}

Kata kunci-ultrasonik, kecepatan gelombang, NDT, UPV, kuat tekan beton

\section{Abstract}

Until now the use of concrete as a building material is still widely used for building structures. It is important to do concrete compressive strength testing as one of the factors to know the quality of a concrete. NDT (Non-Destructive Testing) is a method of solid quality testing without damaging the object. Testing with the NDT method is considered more efficient than the destructive test method. One method for performing NDT testing is by utilizing UPV (Ultrasonic Pulse Velocity).

$U P V$ is a method for estimating concrete compressive strength based on the ultrasonic pulse velocity relationship through concrete with the concrete compressive strength itself. UPV testing works by emitting ultrasonic pulses of $40 \mathrm{kHz}$ through concrete to obtain the travel time of the pulse. Then the resulting time will be calculated the value of its speed and then will be converted into concrete compressive strength.

Concrete compressive strength measurement system for high-quality concrete using UPV method can be designed by utilizing relation between ultrasonic pulse velocity with concrete compressive strength. Based on the test results, the average error value of concrete compressive strength testing is $3.04 \%$ with a maximum error of $6.63 \%$.

Keywords - ultrasonic, pulse velocity, NDT, UPV, concrete compressive strength 


\section{PENDAHULUAN}

Hingga saat ini penggunaan beton sebagai bahan bangunan masih banyak digunakan untuk struktur bangunan seperti jembatan, gedung pencakar langit, dan jalan raya. Benda padat dalam proses pembuatannya tidak bisa terlepas dari masalah kecacatan fisik atau kerusakan yang terjadi di dalam benda tersebut [1]. Sangat penting untuk melakukan pengujian kuat tekan beton sebagai salah satu faktor untuk mengetahui kualitas suatu beton. Kuat tekan beton dapat diuji dengan dua metode, yaitu destruktif dan non-destruktif. Seperti namanya, pengujian destruktif merupakan pengujian yang sifatnya merusak, sedangkan pengujian non-destruktif dilakukan tanpa merusak benda uji. Pengujian dengan metode destruktif ini dianggap kurang sederhana, sebab harus dilakukan di laboratorium dengan biaya yang mahal dan memakan waktu.

Salah satu metode untuk melakukan NDT (Non-Destructive Testing) adalah dengan memanfaatkan UPV (Ultrasonic Pulse Velocity). Pengujian UPV adalah pengujian kuat tekan beton secara tidak langsung, melalui pengukuran kecepatan perambatan gelombang elektronik longitudinal pada media beton [2]. UPV bekerja dengan cara memancarkan gelombang ke beton melalui transduser pengirim. Pantulan dari gelombang akan diterima oleh transduser penerima, sehingga waktu tempuh perambatan gelombang dapat diukur. Waktu tempuh dan panjang lintasan yang didapat kemudian digunakan untuk mengukur kecepatan gelombang pada beton. Kecepatan inilah yang nantinya akan dikonversi menjadi kuat tekan beton dalam satuan MPa sehingga nilai kuat tekan beton dapat langsung diketahui.

Kecepatan gelombang dipengaruhi oleh kekakuan elastis dan kuat tekan beton [2]. Pada beton yang pemadatannya kurang baik atau mengalami kerusakan, gelombang UPV akan mengalami penurunan kecepatan. Perubahan kuat tekan beton pada uji UPV ditunjukkan dengan perbedaan kecepatan gelombangnya; jika lambat maka beton mengalami penurunan kuat tekan, sebaliknya jika cepat maka kuat tekan beton meningkat [3].

Pemanfaatan UPV sendiri mempunyai fungsi sebagai uji kualitas dari bahan padat tersebut sehingga nantinya ultrasonik akan mendapatkan data apakah benda padat tersebut mempunyai kualitas yang bagus atau tidak [4]. Berdasarkan latar belakang tersebut, peneliti akan dilakukan penelitian yang bertujuan untuk merancang dan membuat sistem pengukur kuat tekan beton yang dapat langsung menampilkan hasilnya.

\section{METODE PENELITIAN}

\section{1 Deskripsi Sistem}

Kuat tekan beton merupakan salah satu faktor penting untuk mengetahui kualitas suatu beton. Salah satu pengujian kuat tekan beton adalah dengan cara tidak merusak, yaitu menggunakan metode UPV. Metode ini memanfaatkan gelombang ultrasonik untuk menghitung waktu tempuh pada suatu beton. Hasil waktu yang didapat kemudian digunakan untuk menghitung kecepatan gelombang. Kecepatan gelombang inilah yang kemudian di konversikan menjadi kuat tekan beton dengan suatu persamaan.

Rentang frekuensi yang dapat menembus beton antara $30 \mathrm{kHZ}-180 \mathrm{kHz}$ [5]. Sehingga digunakan modul HC-SR04 sebagai pembangkit gelombang ultrasonik sebesar $40 \mathrm{kHz}$. Gelombang ultrasonik akan dikirim dan diterima melalui transduser ultrasonik. Transduser ultrasonik yang digunakan adalah piezoelektikk yang dapat merambatkan gelombang ultrasonik. Piezoelektrik adalah elemen aktif yang mengubah energi listrik menjadi energi mekanik dan energi mekanik menjadi energi listrik. Piezoelektrik akan menghasilkan energi mekanik saat

IJEIS Vol. 10, No. 1, April 2020 : $11-20$ 
diberikan tegangan listrik dan akan menghasilkan energi listrik saat menerima tegangan listrik [5].

Sebelum gelombang keluaran dari modul HC-SR04 diteruskan ke piezoelektrik, gelombang akan dikuatkan dengan penguat tegangan audio. Hasil gelombang keluaran dari penguat memiliki tegangan sebesar 170 Volt, sehingga gelombang mampu menembus beton. Gelombang akan dikirim oleh transmitter untuk merambat melalui media beton. Gelombang akan diterima oleh receiver, sehingga didapat hasil waktu tempuh gelombang yang merambat melalui beton. Blok diagram sistem UPV yang dirancang ditunjukkan pada Gambar 1.

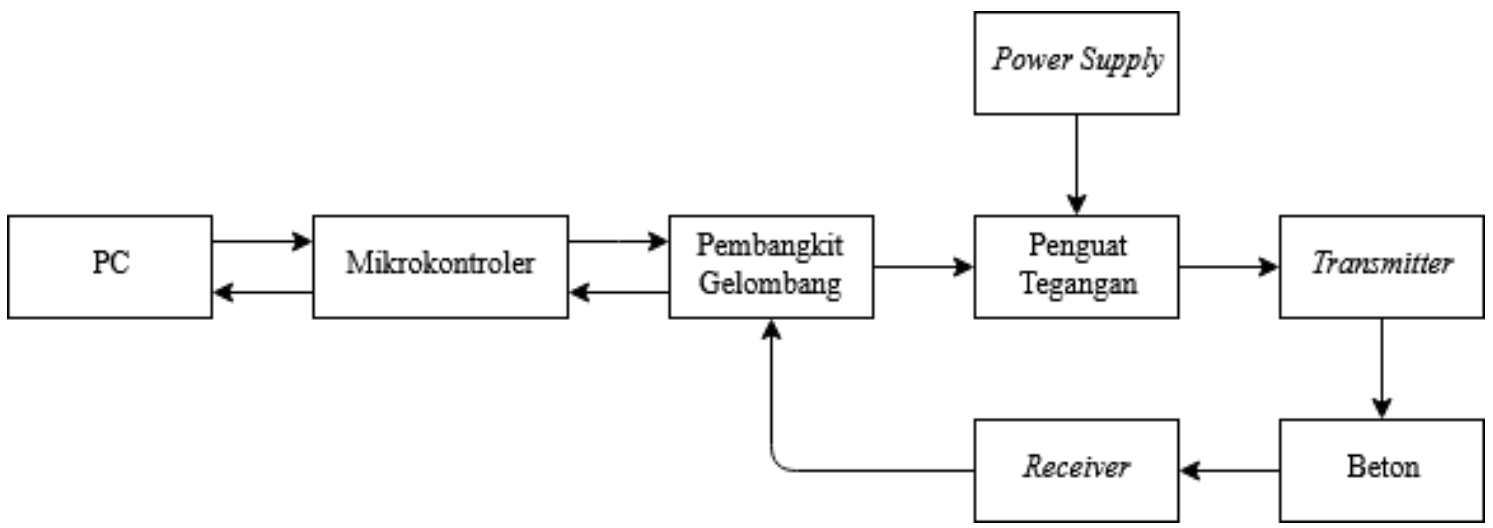

Gambar 1 Diagram blok sistem UPV

Kecepatan gelombang utrasonik didapat dari hasil pembagian antara panjang beton dan waktu tempuh yang dihasilkan oleh rambatan gelombang ultrasonik pada beton. Dengan menggunakan suatu persamaan regresi, kecepatan gelombang ultrasonik akan dikonversi menjadi kuat tekan estimasi. Persamaan regresi didapat dari hubungan antara kuat tekan beton yang sudah diketahui dengan kecepatan yang dihasilkan oleh sistem UPV.

\section{2 Rancangan Perangkat Keras}

Gambar 2 menunjukkan rancangan perangkat keras sistem UPV. Mikrokontroler yang digunakan dalam sistem UPV adalah modul Arduiono Due yang berkerja sebagai pemicu HCSR04, penghitung kecepatan ultrasonik, dan penghitung kuat tekan beton. Arduino due memiliki jumlah clock speed sebesar $84 \mathrm{MHz}$, arduino dipilih karena tidak membutuhkan power yang besar dan tidak membutuhkan waktu pendinginan yang lama [6].

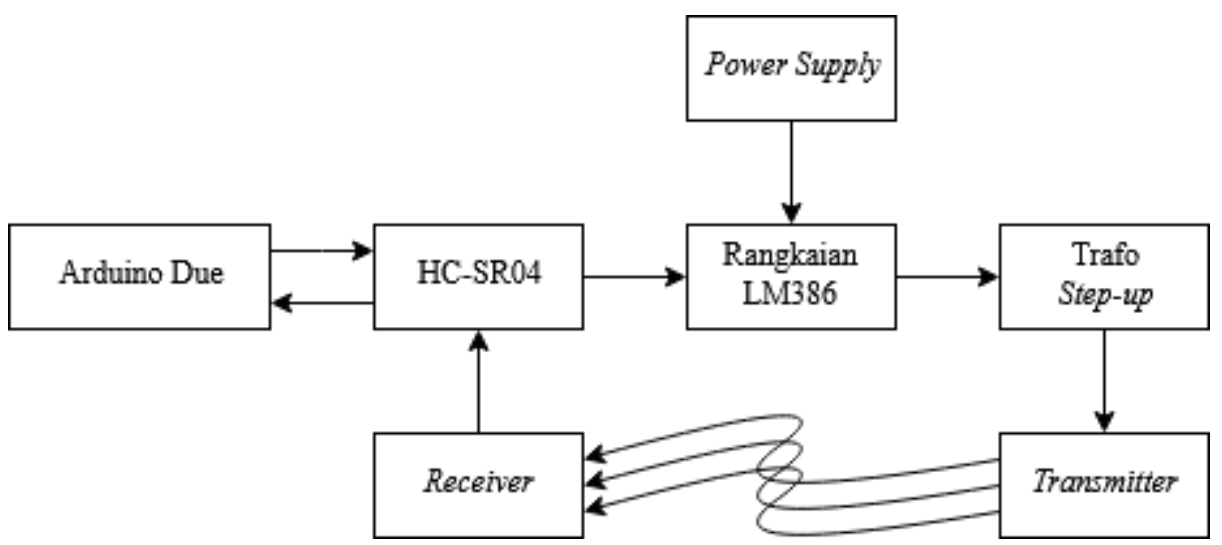

Gambar 2 Rancangan perangkat keras sistem UPV

Modul HC-SR04 akan mengirimkan 8 siklus gelombang setelah mendapatkan pemicu dari mikrokontroler. Gelombang yang dikirim bersifat continue. Modul akan mengirimkan gelombang lagi ketika gelombang pantul sudah diterima oleh receiver. Gambar 3 menunjukkan 
diagram waktu dari pengiriman gelombang ultrasonik. Tegangan yang dihasilkan oleh modul HC-SR04 belum cukup untuk menembus dinding beton, sehingga tegangan harus dikuatkan terlebih dulu dengan rangkaian LM386.

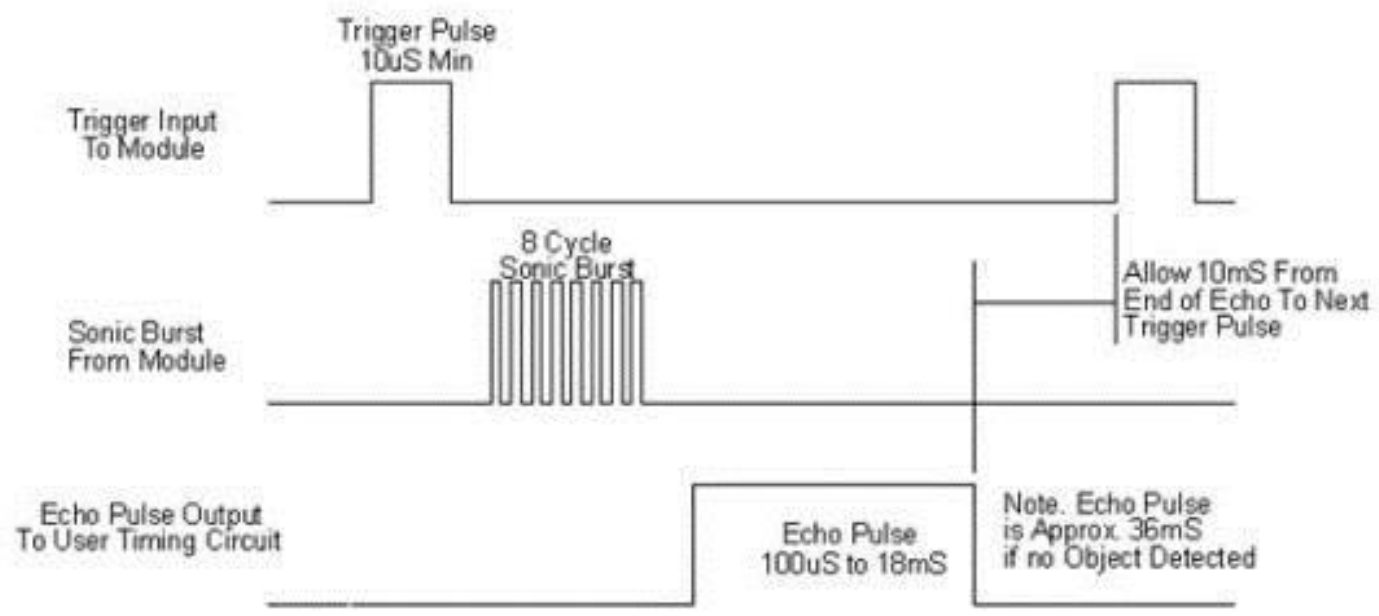

Gambar 3 Diagram waktu dari pengiriman gelombang ultrasonik

Rangkaian LM386 adalah rangkaian penguat audio. Rangkaian ini akan menguatkan tegangan sebesar 20 kali. Rangkaian LM386 diberikan tegangan masukan sebesar 12 Volt, tegangan ini yan akan menjadi tegangan referensi dari keluaran LM386. Tegangan keluaran dari LM386 harus dikuatkan lagi oleh trafo step-up sehingga tegangan keluaran mencapai 170 Volt. Tegangan inilah yang kemudian akan dipancarkan oleh transmitter ke beton. Gambar 4 menunjukkan rangkaian LM386 yang digunakan.

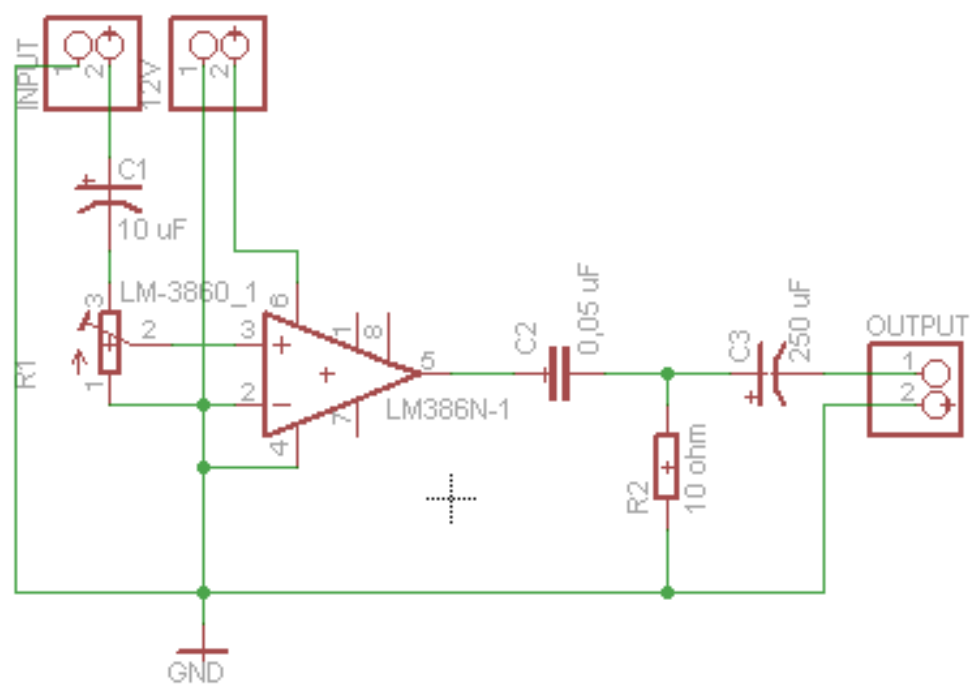

Gambar 4 Rangkaian LM386

Tegangan yang dihasilkan oleh trafo step-up akan dipancarkan pada beton oleh transmitter piezoelektrik. Gelombang hasil rambatan akan diterima oleh receiver piezoelektrik. Hasil rambatan gelombang memiliki tegangan yang sangat kecil sehingga tidak dapat dibaca oleh mikrokontroler. Dalam modul HC-SR04 terdapat IC324 yang digunakan untuk menguatkan tegangan sehingga dapat terbaca oleh mikrokontroler. Waktu tempuh yang dihasilkan kemudian diolah oleh mikrokontroler hingga menentukan kuat tekannya. 


\section{3 Rancangan Perangkat Lunak}

Perangkat lunak dirancang untuk dapat menjadi pemicu untuk HC-SR04, menghitung waktu rambatan gelombang, menhitung kecepatan gelombang, dan menghitung kuat tekan dari persamaan. Pada perangkat lunak pemicu dilakukan dengan memposisikan trigger pin dalam posisi high selama 10ms. Waktu tempuh dihitung dengan memanfaatkan library pemrograman yang telah tersedia pada arduino. Kecepatan dihitung dengan membagi jarak sensor piezoelektronik dengan waktu tempuh yang dihasilkan. Kecepatan tersebut kemudian dikonversikan dengan suatu persamaan regresi untuk mendapatkan nilai kuat tekan suatu beton. Gambar 5 merupakan diagram alir perangkat lunak sistem UPV.

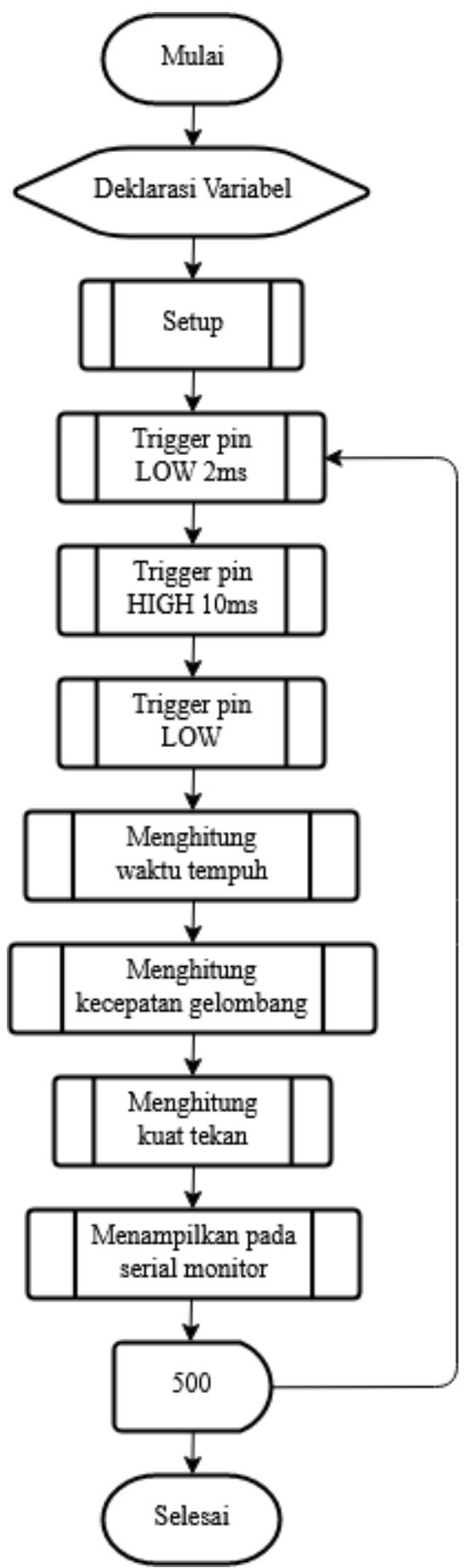

Gambar 5 Diagram alir perangkat lunak sistem UPV 


\section{4 Rencana Pengujian}

Pengujian ini dilakukan untuk mendapatkan hubungan antara kecepatan gelombang ultrasonik dengan kuat tekan beton. Pengujian dilakukan dengan menguji waktu tempuh dengan sistem UPV dan pundit, menguji kecepatan dengan kuat tekan beton, menguji kuat tekan beton dengan sistem UPV, dan menguji kuat tekan beton dengan metode destructive. Pada pengujian ini digunakan variasi beton untuk mendapatkan suatu persamaan hubungan. Adapun pengujian yang dilakukan disajikan pada Tabel 1 .

Tabel 1 Pengujian yang dilakukan

\begin{tabular}{|c|c|c|}
\hline No & Pengujian & Pencapaian \\
\hline 1. & $\begin{array}{c}\text { Pengujian waktu dengan } \\
\text { sistem UPV dan pundit }\end{array}$ & $\begin{array}{c}\text { Mengetahui kesalahan waktu yang dihasilkan oleh } \\
\text { sistem UPV dengan alat yang sudah terpercaya }\end{array}$ \\
\hline 2. & $\begin{array}{c}\text { Pengujian kecepatan } \\
\text { dengan kuat tekan beton }\end{array}$ & $\begin{array}{c}\text { Mengetahui persamaan hubungan antara kecepatan } \\
\text { gelombang ultrasonik dengan kuat tekan beton }\end{array}$ \\
\hline 3. & $\begin{array}{c}\text { Pengujian kuat tekan beton } \\
\text { dengan sistem UPV dan } \\
\text { metode destructive }\end{array}$ & $\begin{array}{c}\text { Mengetahui kesalahan kuat tekan beton yang } \\
\text { dihasilkan oleh sistem UPV dengan alat yang sudah } \\
\text { terpercaya }\end{array}$ \\
\hline
\end{tabular}

\section{HASIL DAN PEMBAHASAN}

Bab ini berisi mengenai hasil dan pembahasan dari pengujian yang telah dilakukan untuk mengetahui hubungan antara kecepatan gelombang ultrasonik dengan kuat tekan beton dan mengukur kuat tekan beton dengan metode UPV. Pada pengujian kecepatan dengan kuat tekan beton digunakan 4 beton berstandar SNI. Pada pengujian kuat tekan beton dengan sistem UPC digunakan 6 beton berstandar SNI. Pengujian dilakukan dengan meletakkan transduser piezoelektronik secara direct pada beton. Sebelum transduser UPV diletakkan pada beton, transduser harus diberikan gel terlebih dulu [5].

\section{1 Pengujian waktu dengan sistem UPV dan pundit}

Pengujian dilakukan dengan menerapkan sistem UPV untuk pencarian waktu tempuh pada beton. Dilakukan perubahan sementara pada perangkat lunak untuk dapat melakukan perhitungan waktu tempuh gelombang. Fungsi loop perangkat lunak hanya digunakan sampai menghitung waktu. Pengujian dilakukan terhadap 4 beton silinser SNI dari Laboratorium Teknik Sipil UGM. Keempat beton dibawa ke Laboratorium Teknik Sipil UGM untuk dilakukan penghitungan waktu dengan pundit, sehingga kesalahan perhitungan waktu pada sistem UPV dapat diketahui. Dari pengujian didapat data hasil seperti yang tersedia pada Tabel 2, hasil waktu dari sistem UPV merupakan hasil rata-rata dari 100 data pengambilan. Dapat dilihat kesalahan rata-rata sistem UPV sebesar 19,76\%, dengan kesalahan minimum sebesar $1,31 \%$ dan kesalahan maksimum sebesar 55,26\%. Anomali tersebut kemungkinan terjadi disebabkan oleh ketelitian pengukuran waktu pada sistem UPV yang kurang baik. Meskipun terdapat anomali sistem UPV dianggap mampu menghitung waktu tempuh. Keberhasilan sinyal menembus beton yang paling utama dipengaruhi oleh rangkaian pembangkit gelombang ultrasonik dan penguat daya yang digunakan [7].

Tabel 2 Perbandingan hasil waktu

\begin{tabular}{|c|c|c|c|}
\hline Beton & Waktu Pundit (ms) & Waktu Sistem UPV $(\mathrm{ms})$ & Kesalahan $(\%)$ \\
\hline A & 28,4 & 26,15 & 7,92 \\
\hline B & 30,6 & 31 & 1,31 \\
\hline C & 47,6 & 54,52 & 14,54 \\
\hline D & 87 & 135,08 & 55,26 \\
\hline \multicolumn{2}{|c|}{ Rata-rata } & 19,76 \\
\hline
\end{tabular}

IJEIS Vol. 10, No. 1, April 2020 : $11-20$ 


\section{2 Pengujian kecepatan dengan kuat tekan beton}

Pengujian dilakukan dengan sistem UPV sampai proses perhitungan kecepatan gelombang ultrasonik. Pengujian ini dilakukan untuk mendapatkan persamaan hubungan yang sesuai antara kecepatan gelombang ultrasonik dengan kuat tekan beton. Sehingga persamaan tersebut dapat digunakan untuk mengkonversi kecepatan menjadi kuat tekan beton pada sistem UPV yang dirancang. Selain dilakukan pengujian kecepatan dengan sistem UPV, dilakukan uji kuat tekan dengan metode destructive.

Hasil pengukuran UPV dan kuat tekan beton dengan metode destructive dapat dilihat pada Tabel 3. Dengan menggunakan bantuan dari trendline pada Microsoft Excel didapat hasil hubungan yang paling baik dengan menggunakan regresi polinomial orde 2. Semakin $\mathrm{R}^{2}$ mendekati nilai 1 maka hubungan yang dihasilkan semakin baik. Hubungan ini yang nantinya akan digunakan untuk mengkonversi kuat tekan beton pada sistem. Gambar 6 menampilkan hubungan antara kecepatan gelombang ultrasonik dengan kuat tekan beton.

Tabel 3 Hasil pengukuran UPV dan kuat tekan beton dengan metode destructive

\begin{tabular}{|c|c|c|}
\hline Beton & UPV $(\mathrm{m} / \mathrm{s})$ & Kuat Tekan Beton $(\mathrm{MPa})$ \\
\hline A & 5927,34 & 72,43 \\
\hline B & 5161,29 & 49,74 \\
\hline C & 2842,99 & 9,06 \\
\hline D & 1147,47 & 3,42 \\
\hline
\end{tabular}

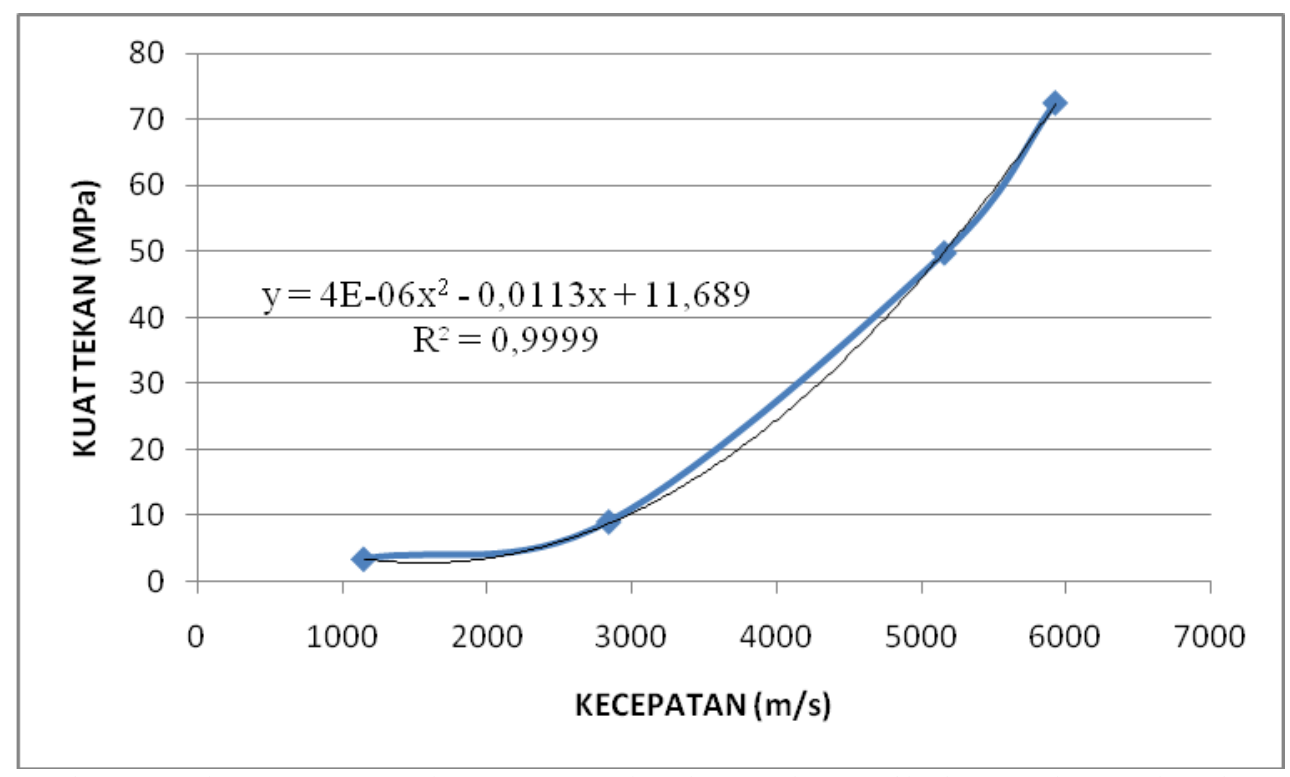

Gambar 6 Hubungan antara kecepatan gelombang ultrasonik dengan kuat tekan beton

\section{3 Pengujian kuat tekan beton dengan sistem UPV dan metode destructive}

Pengujian dilakukan dengan 6 silinser SNI dari Laboratorium Teknik Sipil UGM. Konversi kecepatan gelombang ultrasonik menjadi kuat tekan beton dilakukan setelah persamaan regresi polinomial orde 2 dimasukkan pada perangkat lunak sistem UPV. Pengambilan data dilakukan sebanyak 100 kali pada keenam beton. Data hasil penujian kuat tekan estimasi menggunakan sistem UPV dapat dilihat pada Gambar 7. Kuat tekan beton dengan metode destructive dilakukan di Laboratorium Teknik Sipil UGM dengan menggunakan alat bernama Riehle. Hasil rata-rata kuat tekan beton estimasi 100 beton dan kuat tekan beton dapat dilihat pada Tabel 4. 


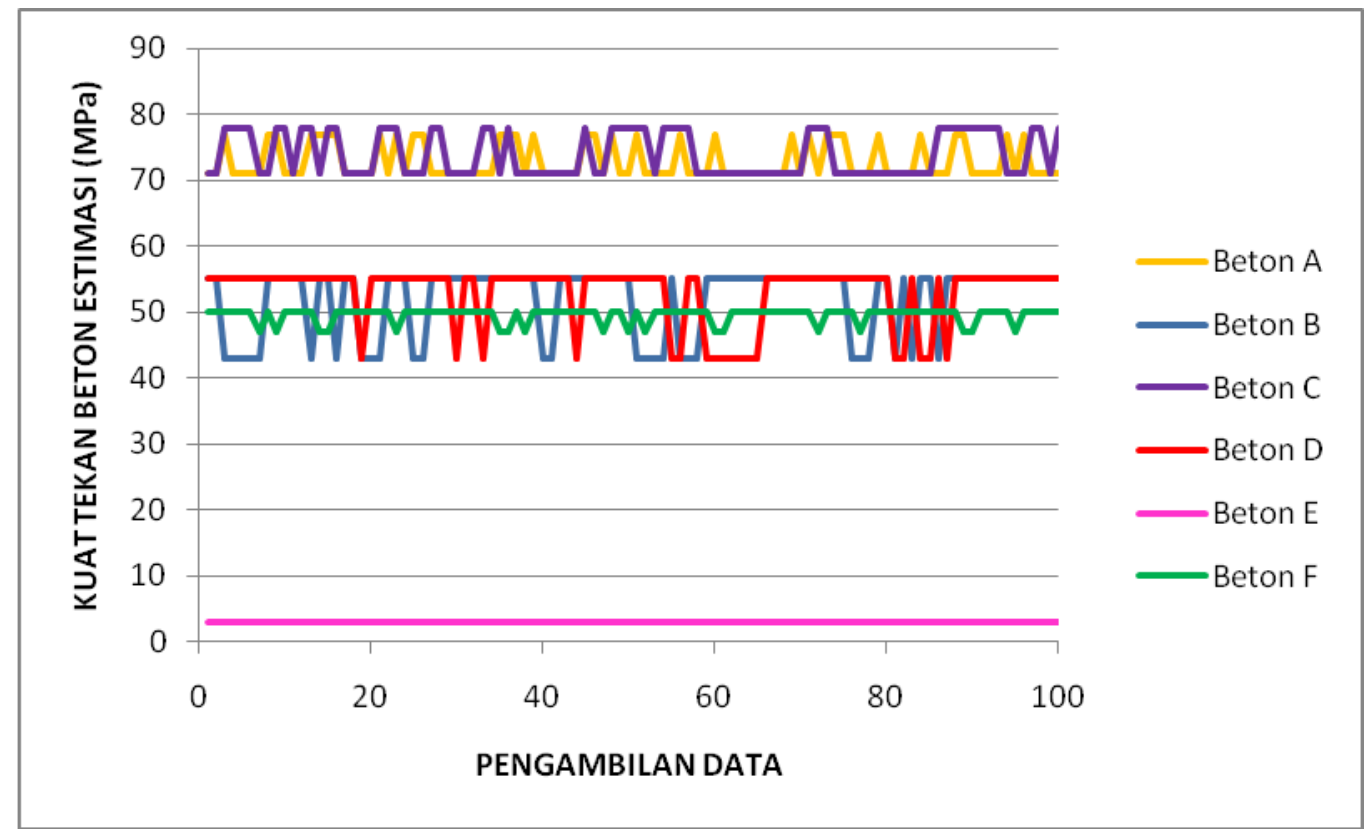

Gambar 7 Grafik hasil kuat tekan estimasi beton

Tabel 4 Hasil kuat tekan beton estimasi dan kuat tekan beton

\begin{tabular}{|c|c|c|}
\hline Beton & $\begin{array}{c}\text { Kuat Tekan } \\
\text { Estimasi (MPa) }\end{array}$ & $\begin{array}{c}\text { Kuat Tekan } \\
(\mathrm{MPa})\end{array}$ \\
\hline $\mathrm{A}$ & 72,92 & 71,61 \\
\hline $\mathrm{B}$ & 51,76 & 52,06 \\
\hline $\mathrm{C}$ & 73,94 & 72,63 \\
\hline $\mathrm{D}$ & 52,84 & 56,59 \\
\hline $\mathrm{E}$ & 3 & 7,96 \\
\hline $\mathrm{F}$ & 49,46 & 51,72 \\
\hline
\end{tabular}

\section{4 Perbadingan Kuat Tekan Estimasi Beton dengan Kuat Tekan Beton}

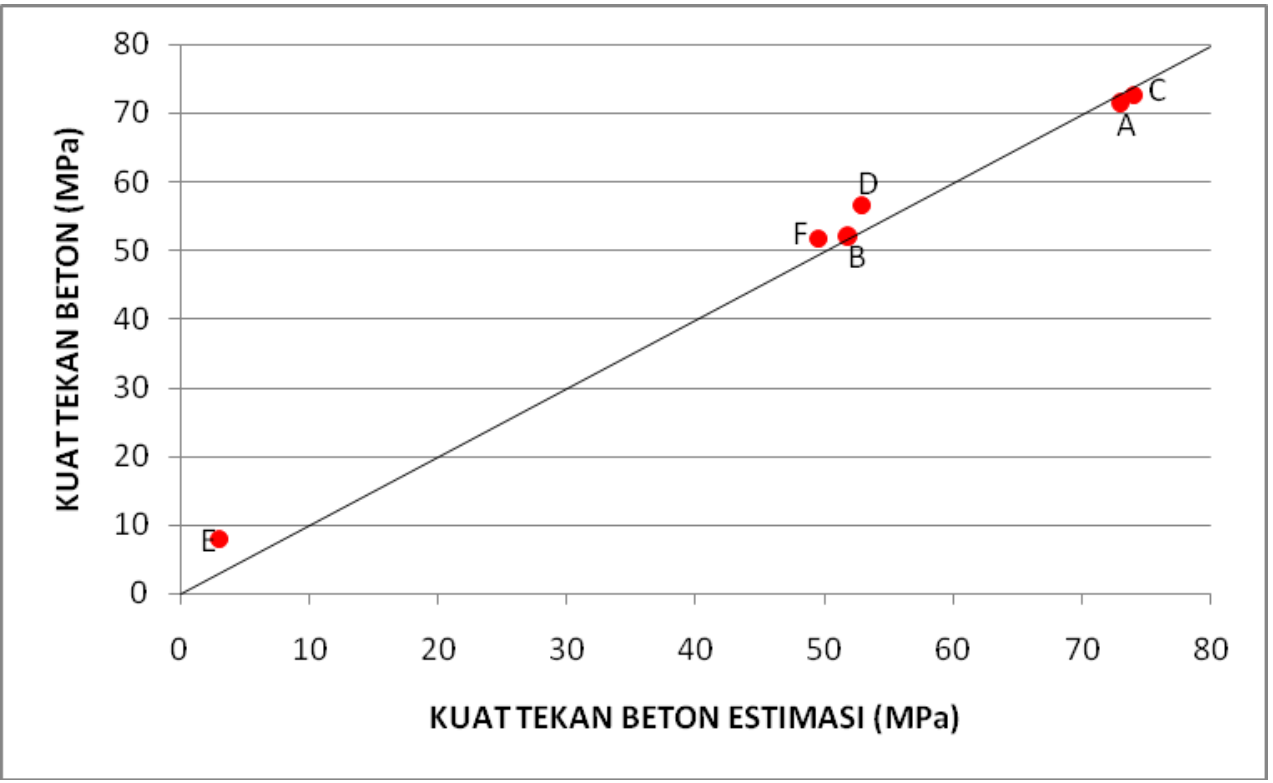

Gambar 8 Grafik perbandingan antara kuat tekan beton estimasi dengan kuat tekan beton 
Grafik perbandingan antara kuat tekan beton estimasi dengan kuat tekan disajikan pada Gambar 8. Grafik tersebut memperlihatkan bahwa nilai kuat tekan beton estimasi terletak di atas garis kontrol, yang berarti cenderung lebih rendah dari pada kuat tekan beton sebenarnya. Persentase kesalahan pengukuran sistem UPV dapat dilihat pada Tabel 5. Kesalahan rata-rata sistem UPV sebesar 12,92\% dengan kesalahan minimum sebesar 0,58\% dan kesalahan maksimum sebesar $62,31 \%$.

Tabel 5 Persentase kesalahan sistem UPV

\begin{tabular}{|c|c|c|c|}
\hline Beton & $\begin{array}{c}\text { Kuat Tekan } \\
\text { Estimasi (MPa) }\end{array}$ & $\begin{array}{c}\text { Kuat Tekan } \\
(\mathrm{MPa})\end{array}$ & Kesalahan (\%) \\
\hline $\mathrm{A}$ & 72,92 & 71,61 & 1,83 \\
\hline $\mathrm{B}$ & 51,76 & 52,06 & 0,58 \\
\hline $\mathrm{C}$ & 73,94 & 72,63 & 1,80 \\
\hline $\mathrm{D}$ & 52,84 & 56,59 & 6,63 \\
\hline $\mathrm{E}$ & 3 & 7,96 & 62,31 \\
\hline $\mathrm{F}$ & 49,46 & 51,72 & 4,37 \\
\hline \multicolumn{3}{|c|}{} & 12,92 \\
\hline
\end{tabular}

Anomali tersebut terjadi pada beton dengan kualitas rendah. Kecepatan gelombang ultrasonik pada beton seharusnya memiliki kecepatan lebih besar dari $3500 \mathrm{~m} / \mathrm{s}$, jika tidak beton pasti memiliki kualitas yang sangat buruk dan kuat tekannya tidak sesuai [8]. Tabel 6 menunjukkan hasil kecepatan gelombang ultrasonik keenam beton yang diuji dengan sistem UPV. Namun untuk perhitungan kuat tekan beton dengan kualitas tinggi, seperti beton A, B, C, $\mathrm{D}$, dan $\mathrm{F}$ memiliki kesalahan perhitungan rata-rata sebesar 3,04\% dengan kesalahan minimum sebesar $0,58 \%$ dan kesalahan maksimum sebesar $6,63 \%$.

Tabel 6 Hasil kecepatan gelombang ultrasonik dengan sistem UPV

\begin{tabular}{|c|c|}
\hline Beton & Kecepatan $(\mathrm{m} / \mathrm{s})$ \\
\hline A & 5580,04 \\
\hline B & 4880,66 \\
\hline C & 5621,1 \\
\hline D & 4920,44 \\
\hline E & 1430,96 \\
\hline F & 4822,26 \\
\hline
\end{tabular}

Pengujian kuat tekan beton menggunakan sistem UPV dapat dipengaruhi oleh banyak variabel, seperti perbandingan campuran, jenis agregat, umur beton, dan kadar air [9]. Hal ini juga dapat menyebabkan anomali yang sangat penting. Dengan tingkat kesalahan yang relatif rendah, sistem UPV dapat digunakan untuk mengukur beton dengan kualitas yang tinggi. Penggunaan metode NDT dengan sistem UPV dapat membantu menyederhanakan dan mengotomatisasi prosedur pengujian kuat tekan beton [10].

\section{KESIMPULAN}

Berdasarkan hasil pengamatan, pengujian, dan analisis pada hasil yang diperoleh, dapat disimpulkan bahwa telah berhasil merancang sistem UPV yang dapat digunakan untuk menentukan kuat tekan beton untuk beton dengan kualitas tinggi. Perancangan kuat tekan dilakukan dengan menentukan hubungan antara kecepatan gelombang ultrasonik dengan kuat tekan beton dan diperoleh persamaan hubungan yang paling baik adalah dengan regresi polinomial orse 2. Kesalahan perhitungan rata-rata yang dihasilkan oleh sistem UPV untuk beton dengan kualitas tinggi sebesar 3,04\% dengan kesalahan minimum sebesar 0,58\% dan kesalahan maksimum sebesar $6,63 \%$. 


\section{DAFTAR PUSTAKA}

[1] T. N. S. Sidiq, A. Rouf, and T. W. Supardi, "Sistem Deteksi Bentuk Kecacatan Benda Padat Menggunakan Teknik Variasi Sudut Ultrasonik," IJEIS (Indonesian Journal of Electronics and Instrumentations Systems, vol. 6, no. 1, pp. 69-80, Apr. 2016 [Online]. Available: https://jurnal.ugm.ac.id/ijeis/article/view/10773. [Accessed: 17-Feb-2018]

[2] H. S. Anggraeni, E. E. Susilo, and S. Wedhanto, "Perbandingan Kekuatan Beton Berdasarkan Hasil Ultrasonik Tes UPV," Konferensi Nasional Teknik Sipil 7 (KoNTekS 7), Oct. 2013 [Online]. Available: http://sipil.ft.uns.ac.id/konteks7/prosiding/020M.pdf. [Accessed: 12-Nov-2016]

[3] M. Hamidian, A. Shariati, M. M. A. Khanouki, H. Sinaei, A. Toghroli, and K. Nouri, "Application of Schmidt Rebound Hammer and Ultrasonic Pulse Velocity Techniques for Structural Health Monitoring," SRE (Scientific Research and Essays), vol. 7(21), pp 19972001, Jun. 2012 [Online]. Available: http://www.academicjournals.org/SRE. [Accessed: 17-Nov-2016]

[4] I. D. Pratomo, A. Rouf, and T. W. Supardi, "Pengukur Jarak Lubang Pada Benda Padat Menggunakan Sensor Ultrasonik," IJEIS (Indonesian Journal of Electronics and Instrumentations Systems, vol. 6, no. 1, pp. 81-92, Apr. 2016 [Online]. Available: https://jurnal.ugm.ac.id/ijeis/article/view/10774. [Accessed: 17-Feb-2018]

[5] S. H. Kee and J. Zhu, "Using Piezoelectric Sensors for Ultrasonic Pulse Velocity Measurements in Concrete," Smart Materials and Structures, vol. 22, no. 11, pp. 11, Oct. 2013 [Online]. Available: http://iopscience.iop.org/article/10.1088/0964-1726/22/11/ 115016/meta. [Accessed: 17-Oct-2017]

[6] P. Acevedo, M. Vazquez, J. Duran, and R. Petrearce, "A Pulse Generator based on an Arduino Platform for Ultrasonic Applications," 2015 Internastional Congress on Ultrasonic, vol. 70, pp. 1096 - 1099, Dec. 2015 [Online]. Available: https://www.sciencedirect.com/science/article/pii/S187538921500975X. [Accessed: 19Feb-2018]

[7] S. Swasoko and A. Rouf, "Rancangan Bangun Pembangkit Pulsa Tiga Sensor Ultrasonik untuk Pendeteksi Kecacatan Beton Berbasis Mikrokontroler," IJEIS (Indonesian Journal of Electronics and Instrumentations Systems, vol. 7, no. 2, pp. 197-208, Oct. 2017 [Online]. Available: https://jurnal.ugm.ac.id/ijeis/article/view/24276/17908. [Accessed: 16-Feb-2018]

[8] B. S. Al-Nu'man, B. R. Aziz, S. A. Abdulla, and S. E. Khaleel, "Compressive Strength Formula for Concrete Using Ultrasonic Pulse Velocity," IJETT (International Journal of Engineering Trends and Technology), vol. 26, no. 1, pp. 9-13, Aug. 2015 [Online]. Available: http://ijettjournal.org/2015/volume-26/number-1/IJETT-V26P203.pdf. [Accessed: 17-Oct-2017]

[9] B. S. Al-Nu'man, B. R. Aziz, S. A. Abdulla, and S. E. Khaleel, "Effect of Aggregate Content on the Concrete Compressive Strength - Ultrasonic Pulse Velocity Relationship," American Journal of Civil Engineering and Architecture, vol. 4, no. 1, pp. 1-5, 2016 [Online]. Available: http://pubs.sciepub.com/ajcea/4/1/1. [Accessed: 12-Nov-2016]

[10] V. Meacci, S. Ricci, A. Bruehwiler, and D. Lootens, "Compact Ultrasound Board for Measurement of Concrete Compressive Strength," 2016 IEEE International Ultrasonics Symposium (IUS), Nov. 2016 [Online]. Available: http://ieeexplore.ieee.org/document/ 7728586/. [Accessed: 12-Nov-2016] 